Paideusis

\title{
Philosophy for Education: Towards Human Agency
}

\section{Heesoon Bai}

Volume 15, Number 1, 2006

URI: https://id.erudit.org/iderudit/1072690ar

DOI: https://doi.org/10.7202/1072690ar

See table of contents

Publisher(s)

Canadian Philosophy of Education Society

ISSN

0838-4517 (print)

1916-0348 (digital)

Explore this journal

Cite this article

Bai, H. (2006). Philosophy for Education: Towards Human Agency. Paideusis, 15(1), 7-19. https://doi.org/10.7202/1072690ar

\section{Article abstract}

This paper considers the contribution of philosophy to education. First, a case is made that the fundamental goal of education is to cultivate human agency in the sense of being able to enact one's freedom (as opposed to conditioned and habituated patterns of thinking, perception, and action) grounded in personal knowledge and ethics. This agency is named as 'autonomy' in this paper.

Secondly, philosophy is conceived as an "art of living," which has ancient roots in both the East and West. An argument is made that identifying philosophical activity as predominantly discursive and theoretical activity entrenches us in the "addiction" to conceptualization and blinds us to seeing that a map is not the territory. Human beings encompass the discursive as well as the non-discursive, theoretical as well as practical dimensions. Hence philosophy as an art of living must address all the dimensions. As an illustration, a number of exemplary philosophic arts pertaining to these practices are explored, including world-making through dialogue (Socratic); autobiographical experiment through philosophical writing (Nietzschean); human-making and self-transformation (Confucian); and mindfulness practice (Buddhist). The case is made that these practices combine to illustrate and demonstrate that philosophy is a practice devoted to the cultivation of fundamental human agency, namely autonomy. (c) Heesoon Bai, 2006

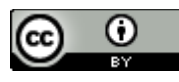

This document is protected by copyright law. Use of the services of Érudit (including reproduction) is subject to its terms and conditions, which can be viewed online.

https://apropos.erudit.org/en/users/policy-on-use/
This article is disseminated and preserved by Érudit.

Érudit is a non-profit inter-university consortium of the Université de Montréal, Université Laval, and the Université du Québec à Montréal. Its mission is to promote and disseminate research.

https://www.erudit.org/en/ 


\title{
Philosophy for Education: Towards Human Agency
}

\author{
HEESOON BAI \\ Simon Fraser University
}

This paper considers the contribution of philosophy to education. First, a case is made that the fundamental goal of education is to cultivate human agency in the sense of being able to enact one's freedom (as opposed to conditioned and habituated patterns of thinking, perception, and action) grounded in personal knowledge and ethics. This agency is named as 'autonomy' in this paper. Secondly, philosophy is conceived as an "art of living," which has ancient roots in both the East and West. An argument is made that identifying philosophical activity as predominantly discursive and theoretical activity entrenches us in the "addiction" to conceptualization and blinds us to seeing that a map is not the territory. Human beings encompass the discursive as well as the non-discursive, theoretical as well as practical dimensions. Hence philosophy as an art of living must address all the dimensions. As an illustration, a number of exemplary philosophic arts pertaining to these practices are explored, including world-making through dialogue (Socratic); autobiographical experiment through philosophical writing (Nietsschean); buman-making and self-transformation (Confucian); and mindfulness practice (Buddhist). The case is made that these practices combine to illustrate and demonstrate that philosophy is a practice devoted to the cultivation of fundamental buman agency, namely autonomy.

[The philosophical act] raises the individual from an inauthentic condition of life, darkened by unconsciousness and harassed by worry, to an authentic state of life, in which he attains self-consciousness, an exact vision of the world, inner peace, and freedom.

-Pierre Hadot, Philosophy as a Way of Life ${ }^{1}$ -

\section{Prospectus}

There is a contribution that I think philosophy is well equipped to make in education. If there is an end to which education is fundamentally committed, and philosophy is superbly equipped to further this end, then philosophy's contribution to education is indisputable. Modern education is dedicated to the cultivation of autonomy as human agency. (As we shall see, this quest for autonomy is not just modern fare.) Through education, we want our fellow individuals to think for themselves and to make reasoned ethical decisions. This capacity to enact one's freedom grounded in personal knowledge and

\footnotetext{
${ }^{1}$ Pierre Hadot, Philosophy as a Way of Life (Oxford: Blackwell Publishers, 1995), 83.

(C) Copyright 2006. The author, Heesoon Bai, assigns to Paideusis the right of first publication and educational and non-profit institutions a non-exclusive license to use this document for personal use and in courses of instruction provided that the article is used in full and this copyright statement is reproduced. Any other usage is probibited without the express permission of the author.
} 
ethics is what I mean by autonomy. ${ }^{2}$ I believe that the call for autonomy as the sine qua non of human agency is urgent today in a world besieged by the global forces of corporatization, fundamentalism, consumerism, and other ideological and structural malaises and inertia that render human beings increasingly powerless to act and reduce them to only behave. ${ }^{3}$

Lately there has been much promotion in Canadian education for cultivating students' social and moral responsibility - a salutary cause, for sure. ${ }^{4}$ School mandates and mission statements have been revised to reflect this. As well, various social skills and moral education programs have been adopted. However, the prerequisite to any responsibility is autonomy founded in personal knowledge and ethics. Only a person capable of autonomy is fit to take up the call to exercise responsibility. Without the cultivation of autonomy, teaching social and moral responsibility may well turn out to be no better than yet another measure of social conformity. ${ }^{5}$

I intend to make a plea for a conception of philosophy as a practice devoted to the cultivation of fundamental human agency, namely autonomy. My arguments will be accompanied by a synoptic exploration of a number of exemplary philosophic arts pertaining to this cultivation, such as worldmaking, dialogue, philosophical writing, and contemplative arts. My selection is certainly not exhaustive, nor its interpretation orthodox, and leaves room for adding other examples and interpretations. In my exploration, I draw from both the Western and Eastern philosophical traditions, the latter being an area that is largely left out of our current scholarship and practice of Philosophy of Education.

\section{In The Beginning Was Philosophy}

The long history of philosophy in both the East and the West shows an incredible diversity of worldviews and perspectives. Still there seems to be a foundational quest underlying them all. The quest, I would surmise, has to do with human agency: how shall human beings apprehend the world and their place within it so as to lead more responsible lives? This question, asked 2,500 years ago and still today, explains why we still read the works of thinkers like Plato and Confucius and draw insights and inspirations from these ancients. The same cannot be said about Alchemy in the study of Chemistry, for instance. Chemistry superseded Alchemy; we consider Alchemy a superstition, not another plausible, competing conception of life.

What is remarkable about the above question regarding human agency is that it was asked at all. If human beings did not see their being-in-the-world as problematic, as needing a fresh

\footnotetext{
2 Autonomy has come under serious attack in these postmodern times. See, for example, Robin Usher and Richard Edwards, Postmodernism and Education (New York: Routledge, 1994). While sympathetic to these postmodern criticisms of autonomy, I maintain that a conception of autonomy that celebrates and promotes the individual capacity to think for oneself and to enact such freedom is an indisputable human good. Thus, I distinguish this modest conception of autonomy from the problematic ontological conception that posits an atomistic view of the individual and privileges the self over the other.

3 I am indebted to James Conroy for sharing his unpublished paper on a study of Hannah Arendt's distinction between action and behaviour. See Hannah Arendt, The Human Condition (second edition) (Chicago: University of Chicago Press, 1998), 38 - 49.

4 An acknowledgment is due to Sheila Rawnsley who, as part of her coursework, surveyed some of the popular programs in use in Lower Mainland schools in B.C. She lists programs like: Second Step (1992); Focus on Bullying (1999); Positive Echoes (1995); The Virtues Project (2000).

5 It troubles many educators interested in moral education, including myself, that a number of the moral education programs in use today (some of which go under the rubric of life skills or social skills education) achieve no better than programming students' behaviour, and even that, with dubious results like students being able to correctly identify moral behaviour on paper and "performing" such behaviour within the instructional setting but not achieving an authentic moral agency that is constant, solid, and ever self-improving.
} 
reconceptualization, then such a question would never have been asked. That the problematization of life and the universe rather suddenly emerged 25 centuries ago seems to suggest that, prior to this time, human beings lived, rather unquestioningly, therefore unself-consciously, within the prescribed, inherited worldviews of their ancestral cultures, be they Olympic Mythologies, the Hindu Cosmology, the tales of Chinese Yellow Emperor, or the story of Ravens. The world and human life were a determinate given, set forth and by and large managed by forces outside humanity; the most that human beings could do was to follow obediently Heaven's Will (or however it was known to different groups). We might characterize this mode of being-in-the-world as heteronomy. Heteronomous human beings would not conceive of themselves as having an individual inner core of freedom to will their own action in accordance with independent thoughts and interpretations about the world. All this changed, however, somewhere between the sixth and fourth centuries B.C.E. Many refer to this remarkable period as the "Axial Age," and mark it as the advent of philosophy in both East and West. ${ }^{6}$ This seems to be the beginning of humanity's quest for autonomy: the self-conscious realization that human beings are to think for themselves and that how we live has all to do with how we conceptualize and apprehend the universe and human life therein. It was as though the childhood of humanity came to an end and a sense of self-responsibility and the possibility of self-making seized homo sapiens.

These axial folks did not banish the gods or God: the world they envisioned was by and large still theistic or animistic. The real change had to do with the burgeoning autonomy: the sense that, notwithstanding the gods' or God's existence, human beings had to do their part in figuring out with their own intelligence such vitally important issues as what kind of place is our universe, what is human nature, what is the purpose of human life, and what is the form of government that best supports human flourishing. In Solomon and Higgins' words, these axial thinkers were "sages, wise men, confident of their own intelligence, critical of popular opinion, persuasive to those who followed them."7 These seekers and lovers of wisdom--among them, Confucius (551-479 B.C.E.) and Lao-tzu (6th century) in China, Siddhartha Gautama (563-483 B.C.E) in India, Zarathustra (ca. 628-ca. 551 B.C.E.) in Persia, and Socrates (470-399 B.C.E.) in Greece--attracted students and disciples and formed schools and learning communities. Different schools mean different cosmologies and speculations about human nature and about the best ways to conduct human life. Lively debate and rivalry raged. Incited by these exemplary teachers, humanity entered, perhaps reluctantly, the young adulthood of self-responsibility and self-care. Such was, it seems, the beginning of philosophy and its quest for selfresponsible human agency or autonomy.

\section{The Axial Age Continues}

The so-called axial period is by no means over, for the quest for autonomy goes on - and must go on. The world awaits another turn of human evolution on the plane of consciousness in the direction of taking better responsibility for how we think and conduct ourselves. We need to become far more responsible than we have been, and there is urgency to this demand now. By all accounts, we are irrevocably damaging the Earth Community and all its biotic members and also are incurring a scale of human suffering that boggles any sane mind. How can we be so blind, heedless, greedy, and violent?

Many are tempted (or committed) to abandon the Axial Quest. They would say that the Quest was a mistake. Human beings should have never left the secure ground of the theistic, teleological worldview. We should have stuck to the notions of the Divine Plan and Heaven's Mandate. We can

\footnotetext{
${ }^{6}$ Many have written about this transitional period. Amongst these are Karl Jespers, Eric Havelock, Morris Berman, and Robert C. Solomon. By "axial," a major paradigm shift, a turning point, is indicated, and in this case, it is a shift in the modality of human consciousness, in our self-perception of what we are about.

7 Robert C. Solomon \& Kathleen M. Higgins, A Short History of Philosophy (New York \& Oxford: Oxford University Press, 1996), 1.
} 
still go back, they are trying to persuade us. Religious fundamentalism is currently sweeping over the world. Ironically, some secular versions of fundamentalism are perhaps even more powerful. Take economic determinism, for instance. The Market Economy has become the current God of the secular, and Transnational Corporations, its new priests.

Fundamentalism and determinism demand heteronomy from us. We recognize fundamentalism and determinism by the telltale sign of ideologies. I like John Ralston Saul's definition of ideology: "Tendentious arguments which advance a worldview as absolute truth in order to win and hold political power." 8 If something is an absolute truth, it is useless, if not stupid, to argue about it, let alone against it. The only reasonable thing to do is to accept it and live in accordance with it. In this way, absolute truth breeds heteronomy. We get to live in a deterministic universe wherein there is no need for the individuals to think critically and creatively, and envision different possibilities of reality. Thus we let the Other (whatever form it might take) govern us, and we are thus relieved from self-responsibility and self-making. We become defectors of the Axial Quest. Philosophy, the original impetus behind the Axial Quest, urges us to get back to it. Childhood cannot be prolonged indefinitely. Time is running out. We need to grow up and embrace autonomy.

\section{The Discovery of Worlds}

Autonomy is the original philosophical project. My historical telling of this notion above left out an account of how autonomy came to be conceived and desired. In one such account, the ancient Greek "discovery" of autonomy with Plato as the key discoverer, we rediscover our ground of autonomy and thereby reaffirm Philosophy's Axial Project.

Plato was gripped by the idea of Ideas. For him, the real world was the world of Ideas, the sphere of nous or Understanding, not the physical, phenomenal world of matter and flux. What made Plato consider the world of Ideas, the suprasensible world, as more real than the sensible world of physical reality? Here is my conjecture: ${ }^{9}$ "Real" is a value term: what is real is what really matters and has the power to affect us most deeply. In my revisionist interpretation, Plato was one of the original "discoverers" of the power of the human mind; that is, the capacity to conceptualize and interpret reality. Physics may be a given to us, but metaphysics is the way we take the given and generate a new order of meaning and power.

We do not "directly" perceive reality: perception is mediated by our conceptualizing minds. The conceptualizing mind superimposes the order of meaning upon the raw materials of sensuous perception. For example, one whose conceptualizing mind is normally functioning does not just see a rose, a certain physical entity, but rather sees the rose through the filter of a particular constellation of meanings, a personal history of experience and knowledge. This particularity renders meaning-making subjective: no one else would have exactly the same meaning-constellation. When ten people gather in a room, although they share one room and may physically see the same things, they inhabit ten separate and subtly or grossly different worlds. Though the physical reality may be the same for everyone insofar as it physically impinges on everybody equally, the reality of understanding and experience - which we shall now call the "world" - emerges as separate particulars on the plane of meaning. It is in this sense

\footnotetext{
8 John Ralston Saul, The Doubter's Companion: A Dictionary of Aggressive Common Sense (Toronto: Penguin Books, 1995), 169.

${ }^{9}$ If I may dare to say so, the trouble with Plato is that he, being utterly impressed with the mind's capacity to form ideas, reifies ideas and creates an independent and privileged reality just for idea-objects. We should be impressed with the mind but reification should be dispensed with. Thus I reject Plato's ontology but accept his epistemology. Through the mind that conceptualizes and forms ideas, we have intelligible access to reality, and the result of such access is what we call world-making.
} 
that we speak of the plurality of worlds and also the idea of world-making. ${ }^{10}$ We should also speak of world-traveling since, as individuals, we do not dwell in one fixed world that we have created but continually generate new worlds; as well, through various modalities of communication, we intersect each other's created worlds. What we are speaking of here is ontology: an inquiry into the meta-physical reality of worlds and how our minds participate in their creation and enactment. This may explain why traditionally ontology was considered the first philosophy.

The key to our world-making and world-traveling is the vigorous activation of the conceptual mind--the mind that articulates reality through images, symbols, concepts, words, and other symbolic expressions. Such articulation of reality is what language makes possible. Of the different languages (images, symbols, and so on), Philosophy's particular fluency lies with concepts. Deleuze and Guattari said it well: "[P]hilosophy is the art of forming, inventing, and fabricating concepts."11 And what a time-honoured, superabundant, exuberant tradition and discipline Philosophy is! Joining Philosophy is like entering the world's oldest and biggest museum, but a teaching museum, where one can find all the concepts that humanity has ever created. But the museum analogy breaks down here because, unlike Philosophy, museums do not manufacture the items to be displayed. The analogy of workshop or studio may work better. Philosophers are conceptual artists who specialize in concept invention and revision. In being apprenticed to them, we learn in their studio the craft of re-interpreting experience, seeing what was subvisible or invisible before, articulating what was only half thought and felt, reconfiguring the subtle body of reality, re-evaluating the values assigned to things, and hundreds of other creative acts of ontological shifts.

Discursive language is a superb carrier of concepts. As such, in philosophers' deft hands, language manipulates concepts, thereby enacting ontological shifts. In this way, language is an ontological "lever" for shifting worlds. This sort of appreciation of the supreme importance of language to our apperception of reality has been the hallmark of philosophy. Recall the oft-quoted line from Wittgenstein: "The limits of my language means the limits of my world." 12 The inseparable, intimate connection between word and world has been the subject of sustained contemplation from Plato to Rorty. Philosophy does not just use words to refer to and describe how the pre-given world is. Its relationship to language goes beyond representation, hence, instrumentality. Rather, philosophy is the tectonic activity of shifting and turning the very foundation of reality, continually bringing forth a new world through a new awareness afforded by language.

How do we enact for Education the above understanding of Philosophy as world-making or, as I would put it, ontological "shape-shifting"? One time-honoured philosophic practice stands out: dialogue. ${ }^{13}$ 'Dialogue' is composed of 'dia' (through) and 'logos' (word), and their combination connotes the peculiar human ability of apprehending reality through the power of words as well as the ability to communicate this apperception with fellow human beings. Worlds are created and shared through words. This wondrous phenomenon is what we have been highlighting in this section. But there is another reason why dialogue is so important to world-making. Through dialogue, we turn information into personal knowledge.

Only personal knowledge is useful to world-making: information, however correct and erudite, does little to contribute to world-making. This is because world-making is a subjective affair taking

\footnotetext{
10 See Nelson Goodman, Ways of Worldmaking (Sussex: The Harvester Press Limited, 1978).

11 Gilles Deleuze \& Felix Guattari, What Is Philosophy? (translation by Hugh Tomlinson \& Graham Burchell) (New York: Columbia University Press, 1991), 2.

12 Ludwig Wittgenstein, Tractatus Logico-philosophicus (translation by D.F. Pears \& B.F. Guinness) (London: Routledge \& Kegan Paul, 1961), 115.

${ }^{13}$ Of course, dialogue is not the only practice that facilitates world-making. Other philosophic arts that I mention later in this essay - for example, philosophical essay writing and contemplative practices -, can be equally useful for this purpose. But in acknowledgment of Socrates and Plato, to whom I attributed the first honour of worldmaking, I chose dialogue as the exemplary practice.
} 
place on the meta-physical plane of personal understanding and interpretation. Mere information, that is, received knowledge not yet appropriated by the subjective core of the individual, fails to contribute to the building of personal knowledge. The form of discourse called dialogue vitally aids this process of appropriation. Let us see how. Here we follow the example of Socrates, our Western exemplar par excellence of dialogic interlocutor.

Dialogue is not simply an informative exchange of thoughts between conversation partners. As Pierre Hadot points out, dialogue has the form of a "combat," albeit amicable as between friends, in which interlocutors compel each other to examine critically, with utmost rigor, their thoughts, perceptions, and impressions for self-contradiction and superficiality, confusion and deception. No part of one's interiority is spared this critical challenge. We cannot have a genuine dialogue if we cannot rise to the challenge of such rigorous examination. For this reason, Hadot reminds us, "[d]ialogue is only possible if the interlocutor has a real desire to dialogue: that is, if he truly wants to discover truth, desires the Good from the depths of his soul, and agrees to submit to the rational demands of the Logos." 14 To emphasize, the aim of such challenge is not to see who wins (the purpose of debate); rather, the aim is personal knowledge and authenticity. Personal knowledge consists of visions and views that are intensely personal and yet equally intensely comprehensive and viable because they have been tested in the interpersonal crucible of dialogue; authenticity is the condition of the self who has withstood these challenges, resulting in a sense of integrity and conviction. Thus personal knowledge need not be merely subjective, that is, idiosyncratic. From the intersection of the private and the public emerges personal knowledge.

I offer philosophical dialogue as a tool of resistance against the increasing emphasis in today's schooling on the acquisition of more and better information and skills. Nowadays, we are not even subtle about what kind of information and skills our students need: those that will render them successful for the global market economy. Here, it is well to recall the ancient animosity between Socrates and the Sophists. The latter specialized in equipping students with useful knowledge and skills so that they could be successful in acquiring wealth and status. Socrates revolted against this popular wisdom of the day and placed before his fellow citizens a rival picture of an educated person: authentic personality realized in personal knowledge and ethics. Socrates upbraided his fellow Athenians for concerning themselves with a life of material and social acquisition and not with cultivation and care of the self. His mission was to "persuade each of you to concern himself less with what he has than with what he is, so as to render himself as excellent and as rational as possible (italics for emphasis)." 15 These words spoken 2,500 years ago are as timely now as then.

\section{Autobiographical Experiment}

I now take a big temporal leap from Plato's legacy, to Descartes, Montaigne and Nietzsche and talk about another gift that Philosophy has for Education. Talking appreciatively about Descartes' legacy goes against the current grain of anti-Cartesian sentiment. But we must not forget Descartes' championing of intellectual autonomy. True: we can find lots of faults with his worldviews and methods of thinking, such as his boundless faith in deductive thinking, his conception of the human self as the disembodied, monological centre of consciousness, or the wholesale devaluing of all that does not possess the mind as dead matter (and these are serious faults). Notwithstanding these, "Descartes' emphasis on what has since been called 'subjectivity' - one's own thought and experience are as authoritative as the established teaching and authority of others, including the Bible - was a truly

\footnotetext{
${ }^{14}$ Hadot, Philosophy as a Way of Life, 93.

${ }_{15}$ Plato, The Collected Dialogues of Plato, 2nd edition, eds. E. Hamilton \& H. Cairns (Princeton, NJ: Bollingen Series, 1961), 36b4 - c6. The particular Dialogue is cited in Apology.
} 
revolutionary move in philosophy." 16

Three hundred and some years have passed since Descartes. Shuffling between modernity and postmodernity, we may not find the idea of self-authority and intellectual autonomy as revolutionary as the Enlightenment folks did in Descartes' own time. In fact, in our current individualist, rights-based age, there is much appearance of having accepted the norm of self-authority. What individuals say and do are to be morally respected and protected by law. Yet in an insidious way, self-authority is a most undermined practice in this age of expert knowledge. Although we may say otherwise, from the way we practice schooling as primarily a business of stuffing students with useful knowledge and skills to the way we fail to function as active citizens in a truly participatory democracy, intellectual autonomy is hardly a societal norm in our highly conformist culture of professionalization and institutionalization of all human functions, as well as of mass media and advertisement-driven consumption. Hence, intellectual autonomy needs more than ever vigorous promotion and nurturance, and I think we are justified in looking to schooling for a major share of this work.

I do not think it a stretch of the imagination to pose a parallel between the intellectual scene that backgrounds Descartes' philosophizing and that of our own. Scholasticism is the theme for these scenic variations. In Descartes' time, scholasticism took the form of Church Doctrines. In our own time, it takes the form of ideologies, whether secular or religious. The most powerful of these ideologies currently is the Doctrine of Progress through Economic Means. Descartes revolted against the massively monolithic authority of the Catholic Church by insisting that true authority lay in the individual's subjectivity and with the capacity to think for oneself. This was an astonishingly bold claim in his time. Since what disables the capacity to think for oneself is the insistent imposition of readymade ideas and channeling of mental activities only to re-arrange acquired ideas, reclaiming of selfauthority has to begin with a self-critical examination of received ideas. Descartes' gift to us was a demonstration of this process of self-examination that is the basis of philosophical thinking. To drive home a cardinal point, philosophical thinking is not just having and manipulating ideas. The latter is a necessary but not a sufficient condition for philosophical thinking. What turns working with ideas into philosophical thinking is the crucial presence and activity of the self that refuses to accept any idea without putting it to the "laboratory" test of one's own interiority. We see this laboratory test demonstrated in Descartes' Meditations. ${ }^{17}$

Descartes begins his series of meditations with a personal confession that he has waited for a long time for this moment to undertake a radical examination, and if necessary a general overthrow, of his acquired beliefs and opinions. The significance of this proposal lies in the implied shift in the position of authority, from what is external to the self to what is internal to the self. The self is a legitimate source of authority insofar as it is an author of its own experience, aided by the power of analysis and interpretation. Now, power is something that can be potential as well as actual. To bring it from the former to the latter takes development and augmentation. What is Descartes' method of developing such power? Essay writing.

In employing the essay style, Descartes was following the example of Michel de Montaigne (1533 - 1592) who, deeply influenced by the Stoic's textual practice of self-reflective writing in Hellenistic times, started the modern genre of essay writing. Essays (from the French, essayer, meaning, 'to try') could be trials of self-interrogation and interpretation upon one's perceptions, feelings, thoughts, and action. The point of such trials is to intensify and widen, to use Foucault's words, and in general to

\footnotetext{
${ }^{16}$ Robert C. Solomon \& Kathleen M. Higgins, A Short History of Philosophy, 184. I must note a parallel revolution (of shifting the ground of authority from the external to the internal position) that took place outside Europe and close to two millennia earlier. The personality behind this earlier revolution was Siddhartha Gautama, the historical Buddha, who taught his disciples to put everything that one hears and learns, including religious texts, to the test of one's own experience.

${ }^{17}$ Rene Descartes, Meditations and Selections from the Principles of Philosophy (translation by John Veitch) (LaSalle, Ill.: The Open Court Publishing Company, 1962).
} 
transform experience. Or to express it in another way, essay writing aims at autopoiesis - self-making. Through clarifying and articulating, reinterpreting and re-evaluating, our experiences, we re-compose the latter and, hence, if appropriately guided, the self. For when we can see, understand, and evaluate our experiences in a better (deeper, wider, clearer, more intense, charged, comprehensive, coherent, meaningful) light, we can come to have a different sense of what we and the world are like, and we can entertain different possibilities of being. Philosophical writing, then, has this potential to transform the self through, shall we say, the alchemical process of transmuting experience, as from lead to gold.

To discuss philosophical writing as a pursuit of autopoiesis would be incomplete without mentioning Nietzsche, our first depth psychologist, although it may seem most inchoate to juxtapose Descartes with Nietzsche. But they stand on one common ground: the philosophical textual practice of transforming the subject. (That Descartes and Nietzsche turned out to represent two diametrically opposed mentalities does not invalidate my claim.) Nietzsche, too, was indebted to Michel de Montaigne for the "experimental" method of writing whereby the self tests its responses to the various topics and situations. As Graham Parkes puts it, it is an experiment in the "laboratory of one's own psyche." In this laboratory, alchemical transmutation of experience into insight and insight into new experience takes place. Nietzsche's writings are the autobiographical records of his constant effort to transform and renew his experience and his life as a whole. Parkes states:

... [Nietzsche's] texts are intended not as expositions of the truth or accounts of the way the world really is, but rather as invitations to entertain a variety of perspectives and consider what changes this effects on one's experience. His psychological insights are presented in the same spirit: not as ultimate truths about the human condition but as hypotheses to be tested in one's experience, as experiments to be conducted in the "laboratory" of the psyche. ${ }^{18}$

What contribution can the above understanding of philosophical essay writing make to Education? Again, our appreciation of a contribution is relative to the context. The general context of today's schooling is that we do not sufficiently encourage and enable students to do their own "experiment" in the laboratory of their psyche. We are still by and large fixated on knowledge transmission and acquisition based on external authority. This is not merely harmless: it deprives human beings of their vitality and agency, and wastes their precious time. Alfred North Whitehead, that gentle, sage-like philosopher, even said that he experienced rage when he thought of the young lives thus wasted. He insists on what he calls the utilization of ideas: ". . relating [an idea] to that stream, compounded of sense perceptions, feelings, hopes, desires, and of mental activities adjusting thought to thought, which forms our life."19 No one hopes to satisfy hunger just by carrying around a bag of groceries or a pocketful of menus: actual food has to be ingested, taken into one's digestive system, and the whole mechanical and chemical process of breaking down, digesting, and metabolizing has to occur. Philosophical thinking is foremost an equivalent process at the level of the mental-conceptual. Ideas are brought into one's interiority and ruminated by means of questioning: "What do I think of this idea? How does it relate to certain views I hold in life? What feelings does this idea provoke and why? If I take this idea seriously, can I continue to live my life the way I have? If others adopted these ideas, how might it change the world?" and so on. We mix the ingested ideas with our own perceptions and feelings, hopes and desires as we mix food with our digestive juices. Ideas that have not been subjected to this digestive process, that is, "ideas that are merely received into the mind without being utilised, or tested, or thrown into fresh combinations" remain "inert." 20 Inert ideas do not contribute to building the person and fueling his or her agentic vitality. The result is an impoverished mind-heart-soul, even if

\footnotetext{
${ }^{18}$ Graham Parkes, Composing the Soul: Reaches of Nietzsche's Psychology (Chicago: University of Chicago Press, 1994), 5.

${ }^{19}$ Alfred N. Whitehead, The Aims of Education (New York: Macmillan Co., 1957), 3.

${ }^{20}$ Alfred N. Whitehead, The Aims of Education, 1.
} 
glutted with "scraps of information," as Whitehead contemptuously called it. Philosophical essay writing, à la Montaigne, Descartes, Nietzsche, is the strong digestive process on the mental plane.

To many undergraduate students long trained almost exclusively to compile and compare expert views and impersonal information under the rubric of a "research paper," the opportunity to write philosophical essays in the voice of "I" can be a paralyzing and disheartening experience. (I am tempted to carry on the digestion analogy and say "dyspeptic experience.") Unable to articulate their own views and insights, or only coming up with trivial, flaccid opinions, lacking depth of analysis and critical understanding, many confess that they feel stupid. Such sight of suffering makes me, their teacher, experience Whitehead's rage. What sort of nonsense enterprise is our formal education that, after 12 or more long years, we end up producing people unable to entertain and articulate their own views that reflect a measure of critical intelligence, imagination, and insight? Are we, in worshipping scientific impersonality and objectivity, training students out of their agentic development which is to render them increasingly articulate, thoughtful, and insightful about their views? In this lamentable situation, philosophical writing must serve as a basic tool of agentic empowerment.

\section{Philosophy as Life Practice}

I now would like to turn to a couple of Eastern philosophical traditions to see what insights and inspirations we can garner. Confucian philosophy has been the mainstay of many Far Eastern cultures for over two millennia. The key aspect of the Confucian philosophy that I wish to explore here is its fundamental commitment to the cultivation of humane sensibility, 仁, (jen) through the communal effort of person-making. In the face of today's world crises typically precipitated by violent confrontation of conflicting ideologies and religions, the cultivation of humane sensibility or benevolence is an urgent task in which philosophy can play a vital and crucial role. We see this possibility superbly instantiated in a philosophy like Confucianism. For Confucians, philosophy is not mainly an intellectual exercise but, as Li Zehou puts it, "pragmatic rationality" that works out the "mutual penetration and merging of sensuality and rationality, individuality and sociality, physiology and sociology, from consciousness to unconsciousness."21 The ultimate goal of Confucian philosophy is the cultivation of the whole person who is fully integrated and harmonized intrapsychically, body-heartmind, and interpsychically with all social and natural orders of the world. It is a philosophy par excellence for holistic education.

In Chinese, the homophonous words, 仁 and 人, both pronounced as 'jen', designate two distinct but intimately related meanings. Firstly, as a zoological designator, 人 means 'human being' (technically, homo sapiens, the species of bipedal primates to which modern humans belong). Its ideogram character indeed shows two spread-out legs joined at the trunk of the body, emphasizing the humans' bipedality. But the other word, 仁, meaning humanity, humaneness, benevolence or kindness, has an additional stroke signifying the number 'two' to the right of the ideogram for the zoological human being. In other words, this word is composed of two characters: "two" and "humans." What has this etymology to do with the way Chinese and Far Easterners influenced by classical Chinese letters and culture think about the world and human beings? Specifically, how does the Confucian thought appropriate this linguistic peculiarity?

In Far Eastern countries such as China, Korea, and Japan, the common notion is that we become human beings, as opposed to being born human beings. For instance, in Korea, one would hear constant references to making and becoming human beings. One of the most frequent expressions of

${ }^{21}$ Li Zehou, "Modernization and the Confucian World." Online. 10 July 2000. <http://www.coloradocollege. edu/academics/anniversary/Transcripts/LiTXT.htm>. This piece is an address delivered at Colorado College, 1999, in a discussion forum titled "The Confucian World." 
moral criticism, especially with respect to young ones, is that so-and-so has failed to become (literally, hasn't been made into) a human being. A more severe criticism is that someone is born with a human mask, meaning that for this person, being human is only a biological endowment. This indeed is the most serious condemnation one can make of another human being. Being human as a biological endowment is a given that a person does not have to earn; but being human as a personal entitlement is a supreme educational achievement demanding a life-long commitment and self-effort. Moreover, recalling the Chinese ideogram for humanity being composed of 'humans' and 'two', this process of becoming human properly pertains to the communicative, interactive realm of social-cultural-political interrelationships that define the progressively expanding order of family, community, country, world, nature, and beyond. The Confucian philosophy is this life-practice of establishing and integrating the self in ever-expanding concentric circles of communities, all the way from household to cosmos.

For Confucius, philosophy is not a field of theoretical knowledge. This does not mean that in Confucian philosophy there is no theoretical inquiry, such as debates about human nature, limits of knowledge, moral conduct, and best forms of government. But such inquiry is never divorced from, but grows out of, the enquirer's own ceaseless life-practice of becoming human. For Confucius, the supreme goal of philosophy is becoming human. The self-cultivation therein encompasses all the aspects of the person: the body, psyche, temperament, mind, sentiment, passions, morals, will, speech, conduct, and so on, down to manners and gestures. Thus, for Confucians, philosophy is understood as a comprehensive art of life-long self-making. Confucius sums up his own pursuit of this art thus: "At fifteen my heart-and-mind were set upon learning; at thirty I took my stance; at forty I was no longer of two minds; at fifty I realized the ming of $t^{\prime} i e n$; at sixty my ear was attuned; and at seventy I could give my mind-and-heart free rein without overstepping the mark." 22

The Confucian conception of philosophy as life-practice and self-making would strike a sympathetic cord with Pragmatists, past and present. Indeed, amongst contemporary pragmatists, there is a vigorous revival and promotion of philosophy as life-practice. Shusterman maintains that "[pragmatism] is no 'evasion of philosophy', but the revival of a tradition that saw theory as a useful instrument to a higher philosophical practice: the art of living wisely and well."23 "Philosophy," he says, "began not with a paradigm text, but with an exemplary life, a dramatic model of living-and dying." 24 He goes on to call upon a whole line of illustrious philosophers in the West, from Socrates to Wittgenstein, including John Dewey and, not surprisingly, Michel Foucault, to illustrate his argument about the main business of philosophy being the practice of self-transformation. Referring to Wittgenstein, Dewey, and Foucault, Shusterman further comments: ". . philosophy had a much more crucial, existential task: to help us lead better lives by bettering ourselves through self-knowledge, selfcriticism, and self-mastery." 25 It is very refreshing and heartening to hear an appraisal like this about philosophy. Philosophy has become all too academic and technical in modern times, neglecting its original mission as "a way of life." 26

To encapsulate, in the face of increasing technicization of teaching and learning, the Confucian philosophy holds up the primary aim of education as the cultivation of humanity. Without negating other aims, especially the aim of subject mastery, the Confucian philosophy insists that still the primary and universal aim is nurturing the humanity (jen) in all. Not only is this a most basic aim but also a

\footnotetext{
22 David L. Hall \& Roger T. Ames, Thinking Through Confucius (New York: State University of New York Press, 1987), VII. This verse is found in Confucius' Analects, 2/4. 'Ming of t'ien' translates as 'the Mandate of Heaven'. In more modern parlance, it means something like knowing one's vocation or calling.

${ }^{23}$ Richard Shusterman, Practicing Philosophy: Pragmatism and the Philosophical Life (London: Routledge, 1997$), 5$.

24 Shusterman, Practicing Philosophy, 17.

25 Shusterman, Practicing Philosophy, 21.

${ }^{26}$ Shusterman is not the only figure in this recent renaissance of philosophy as life-practice. Some other authors I am familiar with are: Richard Rorty, Stanley Cavell, Pierre Hadot, Alexander Nehamas. All these authors, in their respective research specialties, address the theme of philosophy as art of living.
} 
most urgent one in these times of violent conflicts among nations and ethnic groups.

Secondly, in response to the increasing fragmentation and incoherence of postmodernity, the Confucian philosopher of education would say that it is the proper task of education to enlarge progressively our capacity to integrate the self into the ever expanding circles of interrelationship in both human and more-than-human realms. The key to this integration is the cultivation of humane feelings, especially sympathy. "By privileging sympathy as the defining characteristic of true humanity, Confucians underscore feeling as the basis for knowing, willing, and judging. Human beings are therefore defined primarily by their sensitivity and only secondarily by their rationality, volition, or intelligence." 27

Thirdly, the Confucian philosopher educator is dedicated to fostering relationships and establishing a learning community. The cultivation of sympathy can only be carried out through actually living the humane and responsible interpersonal relationships, which necessitates creating and fostering a learning community in the first place. It is in this vein that for Confucius nurturing is prior to teaching, and both are prior to governing. ${ }^{28}$ Thus, the primary role of the Confucian teacher is nurturing leadership, and the primary method is modeling exemplary personality.

Every aspect of the teacher's being and life becomes an illustration and demonstration to students. Textbooks and curricula are secondary to the teacher's own body-mind-heart and her life as a whole. A concept in classical Chinese thought, teaching by the body, recognizes the fundamental importance of embodied teaching and learning wherein the whole personality and life of the teacher and learner are involved. ${ }^{29}$ Such teaching practice is, of course, impossible if the teacher has not seriously engaged in some kind of life-practice of his or her own, being able to demonstrate, as a result, a measure of achievement as an authoritative (not authoritarian) human being. An assumption here, which is characteristic of the Confucian thought, is that the mastery of a particular subject matter is a way of becoming an accomplished human being. Hence, in traditional China, a person who has mastered a subject but remains unexemplary as a human being (say, childish, greedy, or insensitive) represents a failure of education. ${ }^{30}$

There has been a growing tendency to regard, implicitly or overtly, teachers as purveyors of information and technicians of teaching. The Confucian pragmatist call for life-practice and education as the cultivation of the whole person offers a much needed antidote to this tendency.

\section{Contemplative Arts}

I now wish to address something that does not figure centrally in the traditional fare of the Western Philosophy of Education: the art of contemplation. ${ }^{31}$ Although there are different notions of contemplation, the one that I have in mind concerns the practice of freeing ourselves from the

\footnotetext{
${ }^{27}$ Tu Wei-Ming, "Embodying the universe," in Self as Person in Asian Theory and Practice, eds. Roger T. Ames, Wimal Dissanayake, \& Thomas P. Kasulis (New York: State University of New York, 1994), 177 - 186.

28 Joel J. Kupperman, Learning from Asian Philosophy (New York \& Oxford: Oxford University Press, 1999).

${ }_{29}$ To this day, the custom of the student going into the teacher's household to live with him and his family is kept for the study of traditional arts. This custom stems from the classical Chinese thought, of which Confucianism is part, that all learning of non-trivial subjects is at the foundation tacit, embodied, and involves the whole personality.

${ }^{30}$ Kupperman, Learning from Asian Philosophy, 26 - 35.

31 Roger Walsh has a fascinating article in which he argues persuasively that Western philosophers trained exclusively in analytic thinking cannot really understand traditional European philosophies (e.g., Vendanta, Buddhism) because what is involved in the latter is a shift in the paradigm of consciousness for which a different kind of training is required, such as contemplative arts (e.g., yoga, meditation). Roger Walsh, "Can Western philosophers understand Asian philosophies?," in Revisioning philosophy, ed. James Ogilvy (New York: State University of New York, 1992), 281 - 302.
} 
incessant automatic (because conditioned) conceptualization, thereby allowing ourselves to experience what is called non-discursiveness--the state of consciousness that is free from conceptual constructs, including words. At the beginning of this essay, I was vigorously arguing for the primacy of worldmaking through conceptualization. I am now arguing for freedom from conceptualization. But I am not contradicting myself or undoing what I claimed. In all pursuits, there can be imbalance and blindness symptomatic of doing something obsessively, with no conscious control, let alone reflective innovation. Such, I suggest, is the case with our ordinary linguistic-conceptualization: we are so caged up in our thought constructs that we have difficulty realizing that these are just our thoughts, just constructs of reality. This is not to be dismissive of thought constructs. They are the very substance of our world-making, and world-making is human beings' particular and proper way to inhabit and work with reality. But when we are caged up in concepts and are driven by them, we do not have the freedom to make worlds as we see fit. Such freedom requires that we can disengage ourselves, temporarily putting down our building tools to take a break from the construction to reassess and revision our project.

That we are normally caged up in thought-constructs is more serious than not having the scope for virtuoso construction. Being entrenched in thought-construction, we are prone to identifying our notions (pictures of reality) with the reality itself, thereby easily falling into dogmatism. Mistaking the map for the road, we forget that it is made to help us navigate a journey. Map-makers consider their maps the true description of Reality, leading to ideological battles that are not harmless diversions but produce suffering and carnage. September 11 gave us a terrifying example of an ideological battle fought at multiple levels: East vs. West; modernism vs. pre-modernism; haves vs. have-nots; Islamic fundamentalism vs. market fundamentalism, and so on. Each party thinks the other irrational and evil and that the way to peace is to wipe out the other side.

What do we do about mistaking the map for the road? It does no good to tell the deluded that they are deluded. They must step outside their present framework. Is experiencing without maps, that is, without thought-constructs, like asking fish to come out of the water and breathe air? The suggestion is not as radical as it sounds. There are well-established traditions of contemplative practice that we can tap into. One example is the Buddhist practice of introspection known as the mindfulness practice (satipatthana). The key to this practice is experiencing the gaps between thoughts. ${ }^{32}$ Being between thoughts, these gaps are thought-less, that is, non-discursive, free of representation and interpretation. Such gaps can be experienced with knowledge and discipline, which may take time. The key is calming and slowing down the usual frenzy of thoughts and simultaneously increasing attentiveness. The time-tested method is anchoring the attention to one's breathing: trying to keep one's focus on the rhythm of deep breathing and bringing the wavering and wandering attention back to it. ${ }^{33}$ This is the basic practice of Buddhist mindfulness. ${ }^{34}$ It is enough that we talk about the basic practice of witnessing the gap, for we are interested in disengaging the mind from compulsive thought

\footnotetext{
32 Soygal Rinpoche quotes his own teacher Jamyang Khyentze who explains what the Buddhist meditation essentially is: "When the past thought has ceased, and the future thought has not yet risen, isn't there a gap?" Jamyang Khyentze goes on to say that meditation consists of prolonging the gap. Soygal Rinpoche, The Tibetan Book of Living and Dying, eds. P. Giffney \& A. Harvey (New York: Harper Collins Publishers, 1993), 75.

33 Nowadays there is no lack of reputable instructional books on mindfulness practice. One such book that I could recommend to the interested reader with no previous knowledge and experience in the practice is by Venerable Gunaratana. Henepola Gunaratana, Mindfulness in Plain English (Boston: Wisdom Publication, 1991). For a scholarly, scientific account of Buddhist meditation, see: Daniel P. Brown, "The stages of meditation in cross-cultural perspective," in Transformations of Consciousness, eds. Ken Wilber, Jack Engler \& Daniel P. Brown (Boston: Shambhala Publications, Inc., 1986), 219 - 283.

34 Beyond the basic stage that we are talking about in this essay, the Buddhist mindfulness practice (insight or vipassana meditation) in higher stages is an analytic tool for examining the consciousness and arriving at certain psychological "truths" about consciousness (for example, different forms of consciousness, the process of mental construction), as well as certain "truths" about phenomenal existence (impermanence, suffering, egolessness).
} 
construction and giving it an opportunity to experience non-discursive states of awareness in the gap between thoughts.

There is no autonomy when we are conditioned to do something and constantly driven by it. This is addiction. Contemplative arts help us to overcome our addiction to conceptualization, not to stop our practice of thought-construction but to achieve virtuosity in our world-making without dogmatism. The most stubborn dogmatism that plagues us is naive realism: the view that what we perceive is what is "out there," objectively. The experience of non-discursive (objectless, thought-less) awareness can help dispel naive realism and its categorical separation of the subject and object. Virtuoso world-making is possible only when we break out of naive realism and its subject-object dichotomy. Thus, world-making and contemplative practice must go together for mutual support and balance.

\section{Closure}

The common notion that philosophy is impractical should be relegated to the list of outdated myths and popular misconceptions. There is the valid distinction between academic, technical philosophy and philosophy as art of living (which can be technical!), and in modern times the former has been privileged over the latter to the poverty of public life. But, in Philosophy of Education, it is not difficult to appreciate and tap into the conception of philosophy as an art of living. The particular claim to the art of living that philosophy makes is the promotion of autonomy, and it is on this ground that philosophy intersects education.

\section{About the Author}

Heesoon Bai is an Associate Professor at Simon Fraser University in Canada. She teaches in Philosophy of Education, and her research interests are in ethics, epistemology, ontology, ecology, and Asian philosophies. She has published widely in academic journals and edited volumes on topics ranging from democratic education to Zen aesthetics. For more information: http://www.educ.sfu.ca/fri/Bai/ Direct your correspondence to: Faculty of Education, Simon Fraser University, Burnaby, B.C., Canada, V5A1S6.hbai@sfu.ca 